Esta publicación científica en formato digital es continuidad de la revista impresa ISSN-Versión Impresa 0798-1406 / ISSN-Versión on line 2542-3185Depósito legal pp $197402 Z$ U34
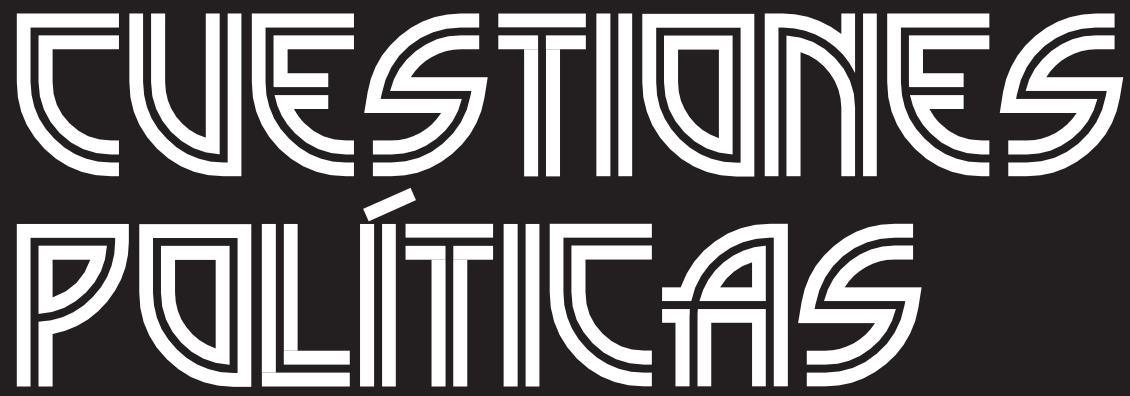

Instituto de Estudios Políticos y Derecho Público "Dr. Humberto J. La Roche" de la Facultad de Ciencias Jurídicas y Políticas de la Universidad del Zulia Maracaibo, Venezuela
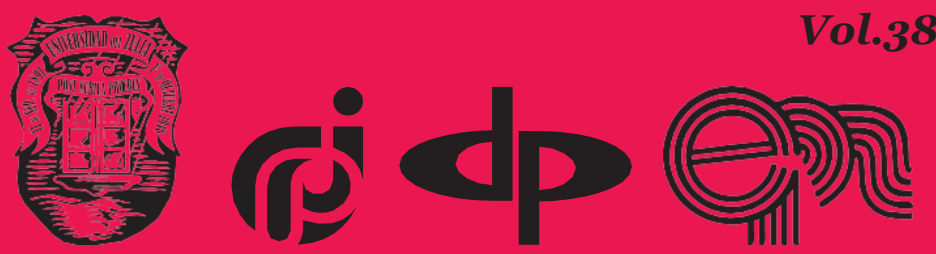

$N^{\circ}$ Especial

2da Parte

2020 


\title{
Internet Media During the COVID-19 Crisis
}

\author{
DOI: HTTPS://DOI.ORG/10.46398/CUESTPOL.382E.2O
}

\author{
Olga Trishchuk * \\ Oksana Grytsenko ** \\ Nadija Figol $l * * *$ \\ Tetiana Faichuk **** \\ Vasyl Teremko *****
}

\section{Abstract}

This article defines the main characteristics of the media during quarantine, analyzes the peculiarity of online media during the crisis caused by the coronavirus pandemic OVID19 and highlights changes in the content of media platforms during the spread of the coronavirus pandemic, considering changes in user interests and new media projects offered especially during this pandemic. General scientific research methods (analysis, synthesis) and special research methods of online media characteristics (content analysis) have been used. Based on the results of the survey, the most popular online platforms were identified during quarantine restrictions, the most vulnerable areas of online media were identified during the crisis, and details of the presentation of material on OVID-19 were analyzed by various means. It is concluded that social quarantine restrictions have led to an increase in activity among users of online media, now focusing on the content of the information and the constant monitoring of the situation of the pandemic, as well as ways to defend against it.

Keywords: online media; online platforms; online publications; social networks; COVID-19 context.

\footnotetext{
* National Technical University of Ukraine Igor Sikorsky Kyiv Polytechnic Institute, Ukraine. ORCID ID: HTTPS://ORCID.ORG/o0oo-0002-4009-8749. Email: triov@ukr.net

** National Technical University of Ukraine Igor Sikorsky Kyiv Polytechnic Institute, Ukraine. ORCID ID: HTTPS://ORCID.ORG/0000-0003-1077-1231. Email: oks-press@ukr.net

*** National Technical University of Ukraine Igor Sikorsky Kyiv Polytechnic Institute, Ukraine. ORCID ID: HTTPS://ORCID.ORG/0000-0002-2503-7243. Email: figol_nadija@ukr.net

**** O. O. Potebnia Institute of Linguistics of the National Academy of Sciences of Ukraine, Kyiv, Ukraine. ORCID ID: HTTPS://ORCID.ORG/0000-0001-6357-8158. Email: tatyanafaichuk@gmail.com

*****Doctor of Sciences in Social Communications, Professor. ORCID ID: HTTPS://ORCID.ORG/o0oo-00029045-7674. Email: v.teremko@ukr.net
} 


\section{Medios de internet durante la crisis del COVID-19}

\section{Resumen}

Este artículo define las principales características de los medios durante la cuarentena, analiza la peculiaridad de los medios online durante la crisis provocada por la pandemia de coronavirus COVID-19 y destaca los cambios en el contenido de las plataformas de medios durante la propagación de la pandemia de coronavirus, considerando cambios de los intereses del usuario y proyectos de nuevos medios ofrecidos especialmente durante esta pandemia. Se han utilizado métodos de investigación científica general (análisis, síntesis) y métodos de investigación especiales de las características de los medios en línea (análisis de contenido). Sobre la base de los resultados de la encuesta, se identificaron las plataformas en línea más populares durante las restricciones de cuarentena, se determinaron las áreas más vulnerables de los medios en línea durante la crisis y se analizaron los detalles de la presentación de material sobre COVID-19 por varios medios. Se concluye que las restricciones de cuarentena social han provocado un aumento de la actividad entre los usuarios de los medios en línea, centrándose ahora en el contenido de la información y en el seguimiento constante de la situación de la pandemia, así como las formas de defenderse de ella.

Palabras clave: medios online; plataformas online; publicaciones online; redes sociales; contexto COVID-19.

\section{Introduction}

According to recent surveys, the impact of online media on audiences has grown significantly, outpacing the credibility and popularity of television, and leaving printed media and radio behind. The Ukrainian Institute of the Future has published a study by O. Ishchenko, which states that the analysis of the media market based on three main indicators - trust, popularity and advertising - puts the Internet in a leading position, leaving printed media and radio far behind and becoming the only competitor with television (Ischenko, 2018). Such popularity of online media in modern conditions determines the relevance of the given study.

Given the rapid development of online media and the emergence of new online platforms, many issues remain outside the scope of scientific interests. The spread of coronavirus pandemic in Ukraine and around the world has become an unexpected and significant factor influencing the work of online media, which is still poorly understood. Therefore, we believe that the purpose of our research is to determine the features of operation of 
Olga Trishchuk, Oksana Grytsenko, Nadija Figol, TetianaFaichuk y Teremko Vasyl Internet Media During the COVID-19 Crisis

online media in Ukraine during the crisis caused by CovID-19, and to define the impact of quarantine restrictions on the operation of online media. These purposes involve solving the following tasks:

- to analyze changes in the interests of online media users during quarantine restrictions;

- to identify how the content of online media has been changing during the quarantine;

- to analyze the transformations in operation of online platforms and the emergence of new online projects during the crisis;

- to identify the reasons for popularity of online media and social networks during the quarantine caused by the pandemic.

The scientific novelty of the study is that:

- the research highlights the specifics of operation of online media during the crisis of COVID-19, in particular, analyzes the negative impact of quarantine conditions on the operation of the media.

\section{Theoretical Framework}

Significant interest in studying online media can be observed with many domestic and foreign scholars, including I. Komashchenko, S. Kvit, S. Mashkova, I. Revunova, J. Gol and many others.

Some researchers, in particular S. Mashkova, when classifying online publications, use the term "online mass medium" (Mashkova, 2006), and L. Gorodenko considers it most accurately to use the terms "network media" or "electronic media" and "electronic mass medium" (Gorodenko, 2011). The justification for using of the term "online media" provided by the British scholar Jim Gol in his work "Online Journalism", where he emphasizes the ability of online media to present information in real or compressed time, is good and interesting (Gol, 2005). However, there still is not any single "general" definition of this term (Revunova, 2013). Many Ukrainian researchers (I. Artamonova, L. Gorodenko, V. Ivanov, B. Potiatynyk, V. Rizun, M. Chabanenko, I. Shkliar) and Western (J. Gol, E. King, R. Craig, R. Reddik, E. Scott) and Russian (O. Vartanova, J. Zasurskyi, O. Kalmykov, V. Kikhtan, L. Kokhanova, K. Lazutkina, S. Mashkov, E. Prokhorov, I. Fomichev) have been studying the problems of online media, however, there still is no single approach to the terminology and features of media operating online. 
Issues of development of various economic spheres during a pandemic are also fundamental for research. It is noted that the normal development of the market without the intervention of the state is at least illusory. The responses that the affected states give to current pandemics must also include social programs aimed at overcoming extreme poverty (Arbeláez-Campillo and Rojas-Bahamón, 2020). Some studies focus on the geopolitical impact of pandemics for the economies and strategic interests of nations that suffer its consequences with the loss of human lives and the allocation of huge resources for Health systems. Economically, pandemics alter the normal functioning markets and erode trust among financial agents (Arbeláez-Campillo et al., 2019).

\section{Methods}

The methods used for this study include, first of all, general scientific methods of analysis and synthesis, which allowed to clarify the advantages and disadvantages of online publications in the pandemic era, to outline the consequences and results for individual business industry processes related to COVID-19.

Descriptive methods are used, in particular the typology method, which is focused on finding stable features and properties of the studied objects. This method allowed to determine the characteristics of online publications and features of publications during the pandemic. The method of typological analysis made it possible to analyze and compare different Internet publications, consider the studied media in terms of how they correspond to the current information situation, outline general trends in editorial policy, rhetoric of materials, ways of presenting important information.

Since the study involved the search, selection, reading and juxtaposition of documentary sources of various Internet publications, the method of analysis of documentary information, including traditional analysis, was used. At the analysis by traditional methods it is possible to allocate the external and internal analysis. External analysis made it possible to draw conclusions about the historical circumstances in which the documents were created (Internet-Media materials), their true motives, allows you to check the reliability and authenticity of the documents. Thus, external analysis considers the document as an element in the system of social relations, and with its help it is possible to understand how important this element is and what role it played.

Internal analysis is an analysis of the content of the document itself. It helps to study the relationship between different elements of the text, the 
modality of the document, the attitude of its author to the topic, and so on. The last stage of the method of analysis of documentary information is the interpretation of the text, which in the process of any traditional analysis allows to penetrate into the essence of the document and identify deep intentions and motives of the communicator, the expected effect of the message, features of the historical moment.

The method of text research is involved, namely content analysis as a method of collecting data on the studied phenomenon or process, which are contained in documents (media materials). For automated information retrieval, resource monitoring was performed, which is based on content analysis and is called content monitoring. The use of this type of content analysis is caused by the need to systematically track trends and processes in a constantly updated information environment.

The article uses Case study - a method of qualitative research in the social sciences, which is to study a single social object (situation, event) in order to understand a wider class of similar cases (class of events). In the context of this article, it is a study of the activities of Internet Media during the COVID-19 crisis in order to provide a generalized explanation of the phenomenon of global changes in various spheres of life.

Various methods of information retrieval and analysis have been used to study the effectiveness of online media. In particular, the operationalization of the studied concepts (online media, electronic media, network media).

\section{Results and Discussion}

Paying attention to the main characteristics of online media, it should be noted that in terms of user perception of information, the information space of online media is audiovisual, while printed media is only a visual source, and radio is only an audio source of information. This winning feature allows not only to reach a wider range of users, but also to provide a much larger amount of information and open new opportunities, operate and influence on the audience in many ways. In addition, the information space in online media in terms of meaning and content can be of informational, entertaining, socio-political and cultural nature. It should be noted that it is one of the criteria for classifying online media, which is not comprehensive enough. Focusing on the classification of online media, most researchers cannot reach an agreement. However, a large group of scholars tend to divide online media into three major functional groups: Internet versions of other types of media (TV sites, radio, periodicals), online media and mixed media (Kotsarev, 2006). 
The study has analyzed five popular online media resource in Ukraine, including "Ukrainska Pravda", "Dzerkalo Tyzhnia", "Ukrinform", "Kyiv Post", "Liga", and used research data from the National Union of Journalists on the situation with advertising in online media (NSJU.org, 2020), the results of surveys conducted by the research company "Gradus Research" on the popularity of social networks and messengers among users (Sostav.ua, 2020), a review of the Google Digital Workshop platform on free online courses during the quarantine (Google Digital Workshop, 2020), monitoring data of the public association "the Institute of Mass Information" on coverage of the coronavirus topic in online media (Imi.org. ua, 2020), articles by ZNAJ.UA on the study of emotionally colored news about the coronavirus (Znaj.ua, 2020).

As the analysis showed, the new harsh realities faced by the world in general and the entire information space in particular, and which have been dictated by the pandemic of the coronavirus Covid-19 forced almost all media to change topics, work style, and some media even suspend their activities. The negative impact of quarantine conditions for Ukrainian media had the most painful effect on advertising. Outdoor advertising has become a complete outsider, due to the closure of shopping malls, retail space and the abolition of any mass events. Most analytis (including Artem Prokopenko (expert at UMG), Mila Krutchenko (director of strategy at Razom Communication), Ksenia Mykhailenko (strategic director of Optimum Media) predict a further decline in advertising due to difficult economic conditions (Dankova, 2020).

Most online publications report a significant reduction (30-40\%) of native advertising or complete cancellation of advertising contracts in April-May 2020 (NSJU.org, 2020). Savhil Musaieva, editor-in-chief of the online publication Ukrainska Pravda, notes that despite the increasement in exposure, the income even from Google advertising has significantly decreased (Goncharenko, 2020). According to a survey conducted in early April 2020 by the National Union of Journalists of Ukraine, $82 \%$ of editors see a sharp loss of advertisers due to quarantine (NSJU.org, 2020).

The analysis showed a rapid reduction in advertising contracts from travel agencies, airlines, concert venues, event agencies, etc., which in turn was transformed into the promotion of advertising for online stores, delivery services, online schools, and the service sector as a whole. At the same time, we see many social advertisings, a surge in the activity of social videos aimed at combating the pandemic, as well as the support of physicians, military personnel, service workers. In part, such advertising is not only informative, such as "actions in case of ill health", "security measures during quarantine", "behavior while being in public places", but also aimed at interaction. 
Thus, most Ukrainian TV channels have launched a social advertisement "thank doctors and everyone who works during quarantine", which not only contains a recording of applause of famous stars and showmen, but also calls for a flash mob from every citizen - to record videos of applause and send it to social networks and channels. These short videos with gratitude from famous people and ordinary citizens are posted on various Internet platforms, including YouTube and Facebook, on pages of leading Ukrainian channels (Ukrinform, 2020).

The conditions of quarantine restrictions allowed online media to take a leading position in the information, communication, and entertainment areas. According to sociological research conducted by the research company Gradus Research at the request of the advertising agency Brand Media, 78\% of respondents preferred Internet resources and social networks (Sostav. ua, 2020). Such high rates for choosing online media are caused by several reasons, including the following:

- Speed. Prompt presentation of information, monitoring of the situation in the country and in the world, which has been changing day by day or even within several hours.

- Remoteness in work, reorganization of work of online media allowed to rapidly involve in the process with minimum expenses on a resource (it touches both workers, and technicians).

- Communication with experts for obtaining their comments the various issues through Skype, Facebook, different messengers, etc.). This allowed to keep the remote format and at the same time get qualified information.

- Interactivity. Involvement of audience into discussions, possibility to respond to stated topics, share news and more.

- Preservation of key security issue today - personal and family.

The rapid growth in popularity of social networks and messengers during the quarantine period has been evidenced by the data from a research conducted by Gradus Research. Facebook, YouTube and Instagram are the undisputed leaders among the audience, and among $78 \%$ of respondents who preferred online resources and social networks, $46 \%$ said that for them social networks have become the main and only channel of information during quarantine. Given such high performance, the editors were challenged to respond quickly and concisely to the demands of society, while not losing focus and diversity in the subject.

Moreover, during the conditions of isolation, the lack of communication with relatives and friends became especially noticeable, which has increased the number of active messenger users. Messengers such as Viber, Telegram, WhatsApp and Skype are the leaders. These messengers are popular due to 
their ease of use, possibility to send smiles, emojis, photos and videos, and availability of video calls function (Sostav.ua, 2020).

Under the conditions of quarantine restrictions of self-isolation, online platforms for self-education, online trainings and video conferencing have become relevant. Many online platforms offer free training or significant discounts on courses in foreign languages, media security, photography, IT, etc. For example, free online and offline courses on the Google Digital Workshop platform are available in 64 countries. The key accent is made on digital marketing and courses that would help in work. The platform offers lessons to train important professional skills. Among them - social skills such as communication, motivation, etc. (Google Digital Workshop, 2020). In addition, another important step in the cultural life of society was the opening of online platforms where you can view theater performances or visit exhibitions in museums and art galleries. This allows users to maintain your cultural habits and needs in conditions of self-isolation, to stay in the rhythm of their usual life, to spend time usefully.

Given the rapid popularity of video conferencing, developers have revised algorithms for using many applications to simplify or extend the capabilities of software. After all, if until recently only large business companies, training centers and media organizations practiced conferences via the Internet, today's realities of life have forced the use of this format of communication in almost all areas. In particular, video conferencing has become an important aspect of judicial and education systems. Some TV channels translated socio-political shows into a video conference format when it was not possible to invite guests to the studio. Online media offer interviews with celebrities, politicians, athletes and public figures in the form of a video conference or live video broadcast.

It is worth noting that videoconferencing has also become an integral part of the work of educational institutions, for meetings, online seminars and presentation of the work of pupils and students. The large-scale project "School Online", launched through forced distance learning, helped students learn basic subjects and showed how effective modern media are in the educational process (Osvita.ua, 2020). Some Ukrainian media, in particular leading TV channels, filled part of their airtime with online lessons. This is one of the largest media space projects together with the Ministry of Education and Science of Ukraine. The lessons were broadcasted both on TV channels (each class had its own channel) and on YouTube, in order to attract a larger number of viewers (Mon.gov.ua, 2020).

Difficult working conditions have forced most online media to change the topic vector of their work or to pause some projects due to the impossibility of their implementation during quarantine conditions. According to Olha Rudenko, Deputy Editor-in-Chief of the Kyiv Post online platform: "People are mostly interested in news about the coronavirus, what concerns their 
lives and safety" (The Lede, 2020), and that is why the topic of pandemic, quarantine and disease control take the major part of the whole information flow. At the same time, online media try to keep the thematic channel in which they have been worked, covering the news about the coronavirus from different angles. For example, the Ukrinform news agency maintains a thematic news section covering the latest developments in politics, culture, tourism, economics, and sports, drawing attention to non-pandemic events in the world and in Ukraine, as well as not showing the statistics on infected and deceased persons on the main page. News about the quarantine and the situation with the coronavirus is highlighted in a separate color, and in text of the information about the number of infected is immediately supported by the number of those who have recovered (Ukrinform, 2020).

According to the monitoring of the public association "Institute of Mass Information", more than $58 \%$ of the total number of materials of national online media were devoted to the topic of coronavirus and fighting against the pandemic. Most materials on CovID-19 were recorded on the Ukrinform website ( $87 \%$ of the total amount of information), and the least were found at "Dzerkalo Tyzhnia" (33\%) and Liga (27.5\%) websites (Imi.org.ua, 2020). At the same time, the materials of the websites were quite constructive, containing advices from experts and links to the Ministry of Health or the WHO.

Most websites, according to the research, started the news with positive statistics or interesting facts, leaving negative data for the second half of the text (Imi.org.ua, 2020). The articles on the websites are mostly emotionally neutral, mainly providing the statistics, as well as the comments of doctors, government officials or experts. Thus, "Dzerkalo tyzhnia" in the news about the coronavirus often refers to the video press briefings of the Minister of Health and the comments of scientists from world universities on the situation with the coronavirus (Zn.ua, 2020).

According to the research conducted by the Institute of Mass Media, many online media used negative language, invented headlines that raised anxiety, and created fake news about panic and coronavirus mortality thus trying to increase website traffic. The website of Ukrainian publication "Ukrainska Pravda" gave statistics on the number of infected, dead and recovered persons on the main page, amending the figures daily and showing the dynamics in graphs. All news about quarantine were provided very briefly and informative. In turn, the Ukrainian publication "Dzerkalo tyzhnia" highlighted "Coronavirus in the World" and "Quarantine in Ukraine" as separate headings, using the numbers of new infections and the names of politicians who predict the situation with the coronavirus in the headlines.

The material is presented with restraint, but often the conclusions of articles have disappointing predictions, such as: "doctors are preparing 
for a new wave of the epidemic" or "the Ministry fears an outbreak of the epidemic with the onset of cold ..." etc. (Zn.ua, 2020). The leader in the ranking of news with a negative emotional color was the website ZNAJ.UA, where $40 \%$ of information was excessively colored with negative emotions, and 60\% contained evaluative judgments (Imi.org.ua, 2020).

The words "panic", "apocalypse", "death", "corpse", "scary shots", etc. were most often used in the materials. Similar words and phrases were contained in the headlines and immediately negatively adjusted the users. In response, the Institute of Mass Media, the online platform Media Detector, Pylyp Orlyk Institute for Democracy, the National Media Association and some other organizations have launched a website for journalists explaining the features of their work during coronavirus pandemic - "AntiCovid. A guide for media people". This online platform provides advice on writing articles, collecting information and using photo-video materials when working on the topic of CovID-19, created to reduce the tension in the information space and publish reliable materials about the coronavirus (Corona.imi.org.ua, 2020).

\section{Conclusions}

Summarizing the information on operation of online media during the crisis caused by the coronavirus COVID-19, we can note significant changes in the content of the majority of media, their working conditions, forecasting their further work, creation of new platforms and projects. It is necessary to note that quarantine restrictions have led to a surge of activity among online media users, focusing on information content and constant monitoring of the pandemic situation, as well as ways to defend against it.

In order to maintain their own safety and the safety of their friends and relatives, communication via the Internet and social networks has become much more popular; the interest in educational programs and entertainment content increased, messengers and video conferencing became more widely used. New realities are forcing us to use online platforms more effectively for self-education, in the field of justice, cultural and socially oriented areas. Having analyzed the data on the coverage of the topic of coronavirus on the Internet, we concluded that there is a significant reduction in emotional tension among users if to compare with the beginning of quarantine. At the same time, there is an active use of negative wordings to create additional panic and increase website traffic. This topic is noted to be extremely relevant and needs further deep studying. 


\section{Bibliographic References}

ARBELÁEZ-CAMPILLO, Diego Felipe; ROJAS-BAHAMON, Magda Julissa. 2020. "Pandemics in globalization times" In: Amazonia Investiga. Vol. 9, No. 27, pp.

3-4.

ARBELÁEZ-CAMPILLO, Diego Felipe; DUDAREVA, Marianna Andreyevna; ROJAS-BAHAMÓN, Magda Julissa. 2019. "Las pandemias como factor perturbador del orden geopolítico en el mundo globalizado" In: Cuestiones Políticas. Vol. 36, No. 63, pp. 134-150.

CORONA.IMI.ORG.UA. 2020. Anticoid. Guide for media people. Available online. In: http://corona.imi.org.ua. Consultation date: 20/03/2020.

DANKOVA, Natalia. 2020. Advertising market during the pandemic. Detector media. Available online. In: https://detector.media/rinok/ ARTICLE/176351/2020-04-14-REKLAMNII-RINOK-U-CHASI-PANDEMII-SHCHOvidbuvaetsya-na-radio-v-didzhitali-ta-zovnishnii-reklami. Consultation date: $03 / 03 / 2020$.

GOL, Jones. 2005. Online journalism. Translated from English by Nesterenko G.A. Kyiv, Ukraine.

GONCHARENKO, Tatiana. 2020. How the Ukrainian media survive in quarantine. Available online. In:https://povaha.org.ua/yak-vyzhyvayutukrajinski-media-v-umovah-karantynu/. Consultation date: 03/03/2020.

GOOGLE DIGITAL WORKSHOP. 2020. Online courses. Available online. In: https://learndigital.withgoogle.com/digitalworkshop-ua/courses. Consultation date: 03/03/2020.

GORODENKO, Lesya. 2011. New media: terminological and cognitive discourse. Ukrainian Journalism. Institute of Journalism. Kyiv, Ukraine.

IMI.ORG.UA. 2020.. How online media is covered COVID-19. IMI monitoring. In: Institute of Mass Media. Available online. In: https://imi.org.ua/ monitorings/yak-onlajn-media-vysvitlyuyut-covID-19-MONITORYNGIMI-I32341. Consultation date: 03/03/2020.

ISCHENKO, Natalia. 2018. The future of media in Ukraine. Available online. In: UIF. https://uifuture.org/publications/23940-budusee-media-vukraine-ukrainskij-institut-budusego-opublikoval-issle/. Consultation date: 03/03/2020.

KOTSAREV, Oleg. 2006. “Typology of Internet Mass Media” In: Scientific Notes of the Tavricheskiy National University named after V.I. Vernadsky. Vol. 
19 (58). No. 5, pp. 321-324.

MASHKOVA, Svetlana Gennadievna. 2006. Internet-zhurnalistika: ucheb. posobie (Internet journalism: a tutorial). Publishing house of Tambov State Technical University. Tambov, Russia.

MON.GOV.UA. 2020. All-Ukrainian school online. Available online. In: https://mon.gov.ua/ua/tag/vseukrayinska-shkola-onlajn. Consultation date: $03 / 03 / 2020$.

NSJU.ORG. 2020. Ukrainian quarantined media are losing revenue sharply and accumulating debts 2020. Available online. In: http://nsju.org/novini/ukrayinski-zmi-na-karantyni-rizkovtrachayut-dohody-ta-nakopychuyut-borgy-doslidzhennyaNSZHU/?FBCLID =IWAR1H1NRMJSCRZ_EKIC4XT3WJO5WHIZP_ wJgpdizkoDlpoSRoV1JXOQ_WQTS. Consultation date: 03/03/2020.

OSVITA.UA. 2020. Fully Ukrainian Online School. Available online. In: https:// osvita.ua/school/school-online. Consultation date: 03/03/2020.

REVUNOVA, Irina. 2013. The concept of online media in media research. Bulletin of Lviv University. Lviv, Ukraine.

SOSTAV.UA. 2020. What do Ukrainians do and what media do they consume in quarantine? Available online. In: https://sostav.ua/publication/ shcho-roblyat-ta-yak-med-a-spozhivayut-ukra-nts-na-karantin-84853. html. Consultation date: 03/03/2020.

THE LEDE. 2020. How the media adapt during a rantin coronavirus pandemic. Available online. In: https://www.thelede.media/ ISTORII/2020/03/19/1288. Consultation date: 20/03/2020.

UKRINFORM. 2020. FILM.UA Group launches videos thanking Ukrainian doctors. Available online. In: https://www.ukrinform.ua/rubricculture/3016688-filmua-group-zapuskae-roliki-z-podakouukrainskim-likaram.html. Consultation date: 03/03/2020.

UKRINFORM. 2020. Quarantine. Available online. In: https://www. ukrinform.ua/rubric-society/3060444-karantin.html. Consultation date: $03 / 03 / 2020$.

ZN.UA. 2020. Coronavirus has become 30\% more contagious. Available online. In: https://zn.ua/ukr/TECHNOLOGIES/koronavirus-stav-na-30zaraznishim-vchenij.html. Consultation date: 20/03/2020.

ZNAJ.UA. 2020. Coronavirus does not spare anyone. Available online. In: https://znaj.ua/society/30o847-kilkist-zarazhenih-ukrajincivzrosla-vdvichi-sered-nih-diti-ye-letalniy-vipadok. Consultation date: 03/03/2020. 


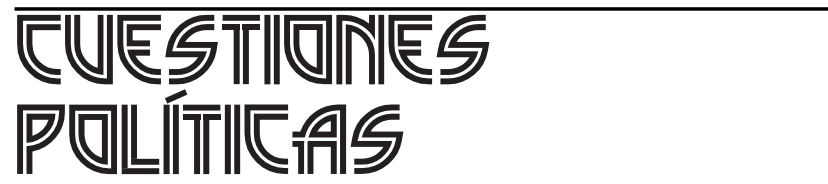

Vol.38 №Especial

Esta revista fue editada en formato digital y publicada en diciembre de 2020, por el Fondo Editorial Serbiluz, Universidad del Zulia. Maracaibo-Venezuela 